The Military Law and the Law of War Review, Vol. 58, No. 1, 2020, pp. 63-84

\title{
The markings of military aircraft under the law of aerial warfare
}

\author{
Dr Mateusz Piątkowski
}

Adjunct professor, Department of Public International Law and International Relations, University of Lodz

The breakthrough innovation of the Wright brothers in 1903 and subsequent developments of aerial technology created significant opportunities for the military, as a new dimension of warfare became an operational space of combat. Many legal questions arise, including the status of air machines deployed by the freshly formed independent air detachments before the outbreak of World War I. From the operational and legal viewpoint, both state practice and international law experts agreed that in order to receive a status similar to warships under the law of naval warfare, military aircraft should bear distinctive insignia, indicating their military character and nationality. This article's aim is to present the origins and evolution of the military markings and their legal significance, as a core element of the military aircraft definition. It needs to be emphasized that only aircraft considered as military can perform acts of hostility and exercise the specific rights granted by the law of air warfare. The analysis will refer to practical challenges for maintaining the classical rule of air warfare, such as the exact location of the markings on the aircraft surfaces, low-visibility insignia (as a way to reconcile legal and operational demands) and the question of relevance of the duty to mark military aircraft in the context of unmanned air platforms.

L'innovation qui a fait connaître les frères Wright en 1903 ainsi que les développements consécutifs dans la technologie aéronautique ont créé de réelles opportunités pour le secteur militaire, alors qu'une nouvelle dimension de la guerre est devenue un espace opérationnel de combat. Cette évolution fait naître de nombreuses questions juridiques, dont le statut des aéronefs déployés par les détachements aériens indépendants formés peu avant l'éclatement de la Première Guerre mondiale. D'un point de vue opérationnel et légal, la pratique étatique et les experts juridiques internationaux s'accordent sur le fait que les aéronefs militaires devraient avoir des insignes distinctifs indiquant leur caractère militaire et leur nationalité, afin qu'ils se voient attribuer un statut similaire à celui des navires de guerre en vertu du droit de la guerre navale. Cet article a pour but de présenter les origines et l'évolution du marquage militaire ainsi que sa signification juridique, en tant qu'élément essentiel de la définition d'un aéronef militaire. Soulignons le fait que seul un aéronef considéré comme militaire peut mener des actes hostiles et exercer les droits particuliers octroyés en vertu du droit de la guerre aérienne. L'analyse fait référence à des défis d'ordre pratique pour maintenir les règles classiques de la guerre aérienne, telles que l'emplacement exact des marquages sur la surface de l'aéronef, la faible visibilité des insignes (comme moyen de combiner exigences juridiques et opérationnelles) et la question de la pertinence de l'obligation de marquer un aéronef militaire dans le contexte de plateformes aériennes sans équipage.

De baanbrekende innovatie van de gebroeders Wright in 1903 en de daaropvolgende ontwikkelingen van de luchtvaarttechnologie crëerden grote mogelijkheden voor de strijdkrachten, aangezien een nieuwe dimensie van oorlogvoering een operationele 
gevechtsruimte werd. Deze ontwikkeling leidt tot veel juridische vragen, waaronder de status van de luchtvaartuigen die door de net voor het uitbreken van de Eerste Wereldoorlog opgerichte onafhankelijke luchtdetachementen werden ingezet. Vanuit operationeel en juridisch oogpunt waren zowel de statenpraktijk als de internationale juridische experts het erover eens dat militaire luchtvaartuigen onderscheidende insignes moeten dragen die hun militaire karakter en nationaliteit aangeven, om een status te krijgen die gelijkaardig is aan die van oorlogsschepen krachtens het recht van de zeeoorlog. Dit artikel heeft tot doel de oorsprong en de ontwikkeling van de militaire markeringen en hun juridische betekenis voor te stellen als een kernelement van de definitie van militaire luchtvaartuigen. Er moet worden benadrukt dat alleen luchtvaartuigen die als militair worden beschouwd, vijandelijke handelingen kunnen verrichten en de specifieke rechten die door het recht van de luchtoorlog worden verleend, kunnen uitoefenen. De analyse verwijst naar de praktische uitdagingen voor het handhaven van de klassieke regels van de luchtoorlog, zoals de exacte locatie van de markeringen op de vliegtuigoppervlakken, insignes met lage zichtbaarheid (als een manier om juridische en operationele eisen met elkaar in overeenstemming te brengen) en de vraag of de verplichting om militaire luchtvaartuigen te markeren relevant is in de context van onbemande luchtvaartuigen.

La revolucionaria innovación de los hermanos Wright en 1903 y subsiguiente evolución de la tecnología aérea dieron paso a oportunidades significativas para los ejércitos, creándose una nueva dimensión de la guerra que se convirtió en un espacio operativo de combate. Esto trajo consigo muchas cuestiones legales, incluido el estatus de los artefactos aéreos desplegados por los recién creados destacamentos aéreos independientes en los prolegómenos de la Primera Guerra Mundial. Desde el punto de vista operativo y legal, tanto los Estados a través de la práctica como los expertos en Derecho Internacional estuvieron de acuerdo en que para acogerse al mismo estatus que los buques de guerra bajo las leyes de la guerra naval, las aeronaves militares debían llevar insignias distintivas, mostrando su carácter militar y nacionalidad. El propósito del artículo es examinar el origen y evolución de estas señales militares y su importancia legal como uno de los elementos principales de la definición de aeronave militar. Debe enfatizarse que solo una aeronave considerada militar puede llevar a cabo actos de hostilidad y ejercer derechos específicos reconocidos por las leyes de la guerra aérea. El análisis aborda los retos prácticos para mantener la vigencia de la regla clásica de la guerra aérea, tal como es el lugar exacto de emplazamiento de las señales exteriores en la superficie de las aeronaves, las insignias de baja visibilidad (como una forma de conciliar las exigencias legales y operativas) y la cuestión de la relevancia del deber de señalar las aeronaves militares en el contexto de las plataformas aéreas no tripuladas.

L'innovazione rivoluzionaria dei Fratelli Wright nel 1903 e i successivi sviluppi della tecnologia aerea crearono significative opportunità per i militari, poiché una nuova dimensione di guerra divenne uno spazio operativo di combattimento. Sorgono molte questioni legali, tra cui lo status delle macchine aeree dispiegate dai distaccamenti aerei indipendenti formatisi appena prima dello scoppio della Prima guerra mondiale. Dal punto di vista operativo e legale, sia la pratica degli Stati che gli esperti di diritto internazionale hanno convenuto che, per ricevere uno status simile a quello delle navi da guerra disciplinate della legge della guerra navale, gli aerei militari dovrebbero portare delle insegne distintive che indichino la loro natura militare e la loro nazionalità. L'obiettivo di questo articolo è quello di presentare le origini e l'evoluzione delle marcature militari e il loro significato legale, come elemento centrale della definizione di velivolo militare. Va sottolineato che solo gli aerei considerati militari possono compiere 
atti di ostilità ed esercitare $i$ diritti specifici concessi dalla legge sulla guerra aerea. L'analisi farà riferimento alle sfide pratiche per il mantenimento delle regole classiche sulla guerra aerea, come l'esatta posizione delle marcature sulla superfice dell'aereo, le insegne a bassa visibilità (come modo per conciliare le esigenze legali ed operative) e la questione della rilevanza del dovere di marcatura dei velivoli militari nel contesto delle piattaforme aeree senza pilota.

Die bahnbrechende Innovation der Gebrüder Wright im Jahr 1903 und die nachfolgenden Entwicklungen der Luftfahrttechnologie schufen bedeutende Möglichkeiten für den Militärbereich, da eine neue Dimension der Kriegsführung zu einem operativen Kampfraum wurde. Es stellen sich viele rechtliche Fragen, einschließlich jener des Status der Luftmaschinen, die von den neu gebildeten unabhängigen Luftkommandos vor dem Ausbruch des Ersten Weltkriegs eingesetzt wurden. Aus operativer und rechtlicher Sicht waren sich sowohl die staatliche Praxis als auch die internationalen Rechtsexperten einig, dass Militärflugzeuge Kennzeichen, die auf ihren militärischen Charakter und ihre Nationalität hinweisen, tragen sollten, um einen kriegsschiffähnlichen Status nach dem Recht der Seekriegsführung zu erhalten. Ziel dieses Artikels ist es, die Ursprünge und die Entwicklung der militärischen Kennzeichnungen und ihre rechtliche Bedeutung als Kernelement der Definition von Militärflugzeugen darzustellen. Es muss darauf hingewiesen werden, dass nur Flugzeuge, die als militärisch angesehen werden, feindliche Handlungen durchführen und die durch das Gesetz der Luftkriegsführung gewährten spezifischen Rechte ausüben können. Die Analyse wird sich auf praktische Herausforderungen für die Aufrechterhaltung des klassischen Gesetzes der Luftkriegsführung beziehen, wie die genaue Lage der Kennzeichen auf den Flugzeugoberflächen, Kennzeichen mit geringer Sichtbarkeit (als Mittel, rechtliche und operative Anforderungen miteinander in Einklang zu bringen) und die Frage der Relevanz der Pflicht zur Kennzeichnung militärischer Flugzeuge im Zusammenhang mit unbemannten Luftplattformen.

Keywords: air warfare, international humanitarian law, military insignia, military aircraft, law of air warfare

\section{INTRODUCTION}

The arrival of military aviation, as a new part of the armed forces, highlighted the issue of aircraft identification. Aside from operational difficulties, such as 'friend or foe' identification in combat, the nineteenth century doctrine of international law struggled to form an acceptable legal framework for air operations in the context of an armed conflict. There was a general understanding that the air warfare regime should entail similar solutions as sea warfare and as a supportive source of obligations - the law of land warfare. The status of military aircraft was compared to that of warships, and it was agreed that in order to exercise the belligerent rights, both type of vessels should distinguish themselves from other objects. This led the French jurist Paul Fauchille to the conclusion that military aircraft should bear a distinctive and visible mark of their nationality. Therefore, the state swiftly adopted the proposal, even before the outbreak of World War I. The aim of the article is to present the historical development of both state practice and specific legal obligation regulating the scheme of aircraft markings. This article provides examples of inconsistent types of insignia and analyses the changing nature of the definition of military aircraft. In addition, the 
article discusses the practice of using so-called 'low visibility' insignia and the problematic issue of unnamed aircraft status.

\section{HISTORICAL BACKGROUND}

The emergence of a characteristic emblem painted on military aircraft surfaces is intertwined with the first regular air services operating within the military structures of states armed forces. In 1909, the French constructor Louis Bleroit developed the novel concept of the Wright brothers plane, and its showpiece air-frame 'Bleroit XI' successfully crossed the English Channel, astonishing military experts. ${ }^{1}$ As a result, the French government decided to launch a training programme for future pilots and conducted a series of experimental tests for the possible adoption of civilian aircraft for combat services. Quickly overcoming the scepticism from senior high ranking officers, France was the first country to establish a permanent structure of military aviation. The breakthrough date in this case was 29 March 1912, when the French Parliament adopted the Bill creating French military aviation. ${ }^{2}$ On 26 July 1912, the new amendment passed, with an order to paint any French military aircraft with the specified and distinctive three-colour roundel. ${ }^{3}$ Simultaneously, the same pattern of military aircraft introduction could be observed among other European Powers. Germany, in 1913, formed their air force detachment (Luftstreitkräfte), which adopted the symbol of German highest military decoration - the Iron Cross (Eiserne Kreuz) ${ }^{4}$ as its marking. Under the order of the German Air Force Inspectorate in the second half of 1918, all aircraft manufacturers were obliged to paint their airframes with a new type of emblem - Balkenkreuz, which was later deployed by the Hitler's Luftwaffe during World War II. ${ }^{5}$

On 11 December 1914, the Royal Flying Corps decided to imitate the French type of markings and adopted the roundel but "with the colors reversed, that is with a red circle inside a blue ring'. ${ }^{6}$ Furthermore, British air force insignia was subjected to various transformations between 1915 and 1970. While the core of emblem remains unchanged (blue ring around red core), there were multiple modifications of the markings - for example, the adoption of the 'night' insignia and the use of the extra colour pallet (white and yellow to improve identification and differentiate from the

1. J Fredriksen, International Warbirds: An Illustrated Guide to World Military Aircraft, 1914-2000 (ABC-CLIO, Santa Barbara 2001) 47.

2. Loi du 29 mars 1912 portant organisation de l'aéronautique militaire, J. O du 31 mars 1912 at $\mathrm{p} 3108$.

3. F De Auer-Veran, Archives De L'Aeronautique Militaire De La Premiere Guerre Mondiale (Service historique de la Defense, Château de Vincennes 2008) 13.

4. GP Neuman, Die Gesamten Deutschen Luftstreitkräfte Im Weltkriege (Dogma, Bremen 2012) 7 .

5. H Nowarra, Fremde Vogel unterm Balkenkreuz (Podzun-Pallas-Verlag GmbH, Friedberg 1981); J-DGG Lepage, Aircraft of the Luftwaffe, 1935-1945: An Illustrated Guide (McFarland \& Company, Inc, Publishers 2009) 49.

6. PD Stemp, Kites, Birds \& Stuff: Over 150 Years of British Aviation, Aircraft of Great Britain Markers \& Manufactures Volume 2 (LULU Author 2010) 31; V Flintham, Combat Codes: A Full Explanation and listing of British, Commonwealth and Allied Air Force Unit Codes Since 1938 (Pen and Sword Aviation, Jefferson 2008). 
French signs). ${ }^{7}$ For instance, during the Battle of Britain, the Royal Air Force (RAF) aircraft displayed three different types of symbols. The uniqueness of RAF markings is the presence of an additional painting located on the rudder (fin-flash).

A similar transformation could be observed in the US' military aviation. While the distinctive 'White Star' has been displayed in all types of deployed insignia (with the exception of the American Expeditionary Forces activity at the European theatre in 1917-18, where in order to maintain Allied types of marking, the US aviation used the tricolour roundel), the specific composition of the markings evolved during that stage of history. ${ }^{8}$ After World War I, the US military aircraft displayed the roundel-type insignia with the 'White Star' inside the blue circle and a red dot in the centre.' Experience gained by the US aircrews during combats with Japanese aviation underlined the need for a new marking shape. In 1943, the distinctive stripes were added to the 'White Star' symbol, and, since 1947 this type of insignia has been displayed by all military aircraft of the US Air Forces (National Star Insignia). ${ }^{10}$

The Japanese national roundel (hinomaru - 'Sun disk') remains in use and unchanged since the establishment of the first Japan air force detachment in 1912 and its successor the Japan Air Self-Defense Air Force in 1954. Also, the Imperial Russian Air Service introduced a tricolour roundel (based on the colours of the national flag) in 1912, and the Soviet Air Force aircraft displayed the distinctive 'Red Star' emblem from 1917. After the dissolution of the USSR, the Russian Federation Air Force approved further use of the 'Red Star' insignia. In 2010, the Russian Parliament readopted an updated version of the 'Red Star' with new borderline to reflect the colour of the Russian national flag. ${ }^{11}$

\section{THE ORIGINS OF DUTY TO MARK MILITARY AIRCRAFT WITH 'DISTINCTIVE INSIGNIA'}

The first legal research concerning the status of airspace, the legality of air warfare and the question of military aircraft definition was conducted by the French jurist Professor Paul Fauchuille. In 1901, in his article entitled Le domaine aérien et le régime juridique des aérostats, the aviation law expert presented breakthrough ideas on the legal status of air domain, championing the idea of 'freedom of the air'. ${ }^{12}$ Fauchuille followed the van Bynkershoek concept, already adopted in the customary law of the sea, claiming that the status of airspace should be analogical to the high seas. The great interest of international academia awarded Fauchille with the appointment to the position of rapporteur of the International Law Institute ( $L^{\prime}$ Institute De Droit International). In 1902, the French jurist presented at session a detailed report

7. R Higham, 100 Years of Air Power \& Aviation (Texas A\&M University Press, Austin 2004) 40 .

8. J Gamez, 'The Evolution of the U.S. National Air Insignia: 1861-Present' (2000) Raven $57,66$.

9. Evolution of the United States Aviation Marking available at <https://www.history. navy.mil/research/histories/naval-aviation-history/aircraft-markings.html> (accessed 1 October 2020).

10. Technical Manual, Exterior Finishes, Insignia and Markings, Applicable to USAF Aircraft, 3-2.

11. Available at <https://ria.ru/20100311/213524551.html > (accessed on 1 October 2020).

12. P Fauchille, 'Le domaine aérien et le régime juridique des aerostats' (1901) Revue générale de droit international public 414. 
on the current legal framework of aerial domain with the draft of the regulation. ${ }^{13}$ Article 2 of Fauchille's draft of 1902 stipulated that 'public (military included) or private aircraft should present external markings' which would allow for swift visual identification of the nationality of the aircraft. ${ }^{14}$ The French jurist underlined that a 'stateless' aircraft could be compared to pirate vessels and treated accordingly, as in the law of the sea. ${ }^{15} \mathrm{He}$ excluded the possibility of allowing military aircraft to operate under a false flag, pointing out the differences between air and naval warfare. ${ }^{16}$ At same session, Fauchille asserted that international law concerning the use of aviation should be comprehensive, addressing both times of peace and war. ${ }^{17}$ As a consequence, during the session of the International Law Institute in 1911, he proposed a complete code of the law of aerial warfare ${ }^{18}$ Article 2 of the 1911 draft underlined that only military aircraft are entitled to exercise belligerent rights. It was firmly highlighted that the aircraft need to carry 'clearly distinctive and visible markings' ${ }^{19}$ The participants of the discussion invoked in this place that the potential penalty for failure to comply with Article 2 of the draft will be the denial of the combatant status of the crew. ${ }^{20}$

It should be emphasized that the French jurist was not the only legal researcher examining the relationship between the international law and the law of aerial warfare. Another French jurist, V Le Moyne, in his doctoral thesis, agreed with the Fauchille approach on the constitutive elements of military aircraft status, upholding this

13. Annuaire De L'Institut De Droit International, Vol. XIX, Session de Bruxelles 1902.

14. 'Les aérostats publics, militaires et civils, arboreront leurs flammes respectives, les premiers sur le côté de leur nacelle elles seconds sur leur enveloppe au-dessous du drapeau national'. Ibid at 26.

15. 'Un aérostat sans nationalité serait un pirate'. Ibid at 28.

16. Ibid at 29. 'Here the stricter rule of land warfare was preferred to the more lenient naval rule (...).' DHN Johnson, Rights in Air Space (Manchester University Press, Manchester 1965) 40.

17. In fact, international law did not follow the 'comprehensive' approach of Paul Fauchille. In 1910 and in 1919, during the preparation of the treaties regarding the international air navigation, the question of air warfare was generally excluded from the scope of the conventions. This led to the division between the regime regulating the use of aircraft in time of peace (international aviation law) and in time of war (law of air warfare). Distinction had been confirmed by Art 89 of the 1944 Convention on International Civil Aviation (also known as the Chicago Convention). It is generally confirmed that the vague definitions of 'state aircraft used in military services' (Art 3 of the Chicago Convention) are not sufficient in the circumstances of air warfare, as they solely focused on the 'use' aspect (see M Gestri, 'The Chicago Convention and Civilian Aircraft in Time of War' in N Ronzitti and G Venturini (eds), The Law of Air Warfare: Contemporary Issues (Eleven International Publishing, The Hague 2006) 139-40; JP Nonig, The Legal Status of Aircraft (Martinus Nijhoff, Leiden 1956) 38-39; EM Giemulla, 'Chicago System: Genesis and Main Characteristics' in EM Giemulla and L Weber, International and EU Aviation Law: Selected Issues (Wolters Kluwer Law \& Business, The Hague 2011) 53-54; M Milde, International Air Law and ICAO (Eleven International Publishing, The Hague 2008) 61.

18. Annuaire de L'Institut de Droit International, Vol. XXIV.

19. 'Sont considérés comme belligérants, sousréserve de ce qui est dit à l'article 3, les aérostats militaires, c'est-à-dire affectés par l'Etat à un service militaire et placés sous le commandement d'un officier en uniforme de l'armée, de terre ou de mer. Tous aérostats militaires doivent porter, attaché d'une manière visible à leur enveloppe, un signé distinctif de leur Caractère.' Ibid at 28. 20. Ibid at 65 . 
requirement in his own draft (Article 7). ${ }^{21}$ Further and more detailed studies on this subject were undertaken by James Spaight, British lawyer and military pilot. Spaight's conclusions and observations are especially significant due to his first-hand experience gained as an aviator. In his research, he categorically underlined the value of the principle of distinction, highlighting that its status must be considered as 'necessary' in air warfare. Spaight might be credited with the formulation of the definition of military aircraft, which stipulates that the aircraft shall: (1) operate under the military jurisdiction, (2) display the visible national insignia, and (3) be manned by air crew subjected to military discipline and respecting the laws of war. ${ }^{22}$ With only minimal additions, the definition of the military aircraft proposed by Spaight was at large followed by the Hague Rules of Air Warfare of 1923 (HRAW). ${ }^{23}$ The validity of the rule was repeated in the state's expert manuals (San Remo Manual of 1994 and HPCR Air and Missile Warfare Manual of 2009). ${ }^{24}$

It might be stated without much controversy that between 1912 and 1914 a norm of customary character emerged, which imposed a duty on states to apply the national military markings on the outer surfaces of all aircraft. ${ }^{25}$ As observed in the examples above, the practice in that particular subject was universal, as every state forming its own air force detachment adopted its own scheme of insignia. ${ }^{26}$ The subjective element of customary international law - opinio iuris - might be at first a little ambiguous to decode. ${ }^{27}$ In hindsight, the states were rather guided by the operational necessities that were driven by the legal undertaking. The priority was visual identification, which allow aviators and other personnel to verify the nationality of the

21. V Le Moyne, Le Droit Futur De la Guerre Aerienne: These Pour Le Doctorat (Université de Nancy 1913) 109-259.

22. J Spaight, Aircraft in War (Macmillan, Basingstoke 1914) 114.

23. See Arts 3 and 14 'Rules concerning the Control of Wireless Telegraphy in Time of War and Air Warfare'. Drafted by the Commission of Jurists at The Hague, December 1922-February 1923.

24. 'Military aircraft must bear an external mark indicating nationality and military character, be under command of a person duly commissioned or enlisted in military service and be crewed by military personnel.' Air Operations and the Law (2014) Judge Advocate General's School 20; "Military aircraft" means an aircraft operated by commissioned units of the armed forces of a state having the military marks of that state, commanded by a member of the armed forces, and manned by a crew subject to regular armed forces discipline'; JSP 383, The Joint Service Manual of The Law of Armed Conflict (2004) at 12.10311 'military aircraft means an aircraft operated by commissioned units of the armed forces of a State having the military marks of that State, commanded by a member of the armed forces and manned by a crew subject to regular armed forces discipline'; Rule 13(j) of the San Remo Manual on International Law Applicable to Armed Conflicts at Sea; "Military aircraft" means any aircraft (i) operated by the armed forces of a State; (ii) bearing the military markings of that State; (iii) commanded by a member of the armed forces; and (iv) controlled, manned or preprogrammed by a crew subject to regular armed forces discipline'; Rule 1(x) of the HPCR Air and Missile Warfare Manual.

25. 'The military aircraft of each state should be marked in some characteristic way and the national colour should be displayed as conspicuously as the construction of the aircraft permits, so that nationality can be determined at a distance.' WE Ellis, 'Aerial Land and Aerial Maritime Warfare' (1914) 8(2) AJIL 267.

26. L Rolland, 'Les Pratiques De La Guerre Aerienne: Dans le Conflit De 1914 et Le Droit Des Gens' (1916) Reveu Generale dr droit international public 519.

27. E.g. J Spaight considered that '(...) what, exactly, the mark should be is a question for discussion and arrangement between the Powers'; Spaight (n 22) at 72-73. 
approaching aircraft. ${ }^{28}$ On the other hand, the states started to associate this practice with the legal requirement, emerging from the overall duty of every belligerent to properly distinguish members of the military forces and warships. ${ }^{29}$ The matter with regard to naval and land warfare was already codified by the VII Hague Convention of 1907 (Article 1) and Hague Regulation of 1907 Concerning Laws and Customs in Land Warfare (Article 1). Presentation of the emblems, flags or insignia indicating nationality became an agreed standard in general international law of war at the beginning of the twentieth century. ${ }^{30}$ Moreover, the strict definition of the warship in the regime of naval warfare could be attributed to the whole range of rights which might be exercised exclusively by them, the question of immunity included. ${ }^{31}$ In fact, the immaterial object became the subject of specific legal provisions. ${ }^{32}$ The "personification' of the warships was a gateway to accepting a similar analogy in the context of the military aircraft. ${ }^{33}$

The conduct of World War I fully confirmed that the duty to mark military aircraft is a part of customary international law. ${ }^{34}$ Moreover, the norm became an integral part of the military aircraft definition. ${ }^{35}$ This was confirmed by the comprehensive draft code of the law of air warfare: HRAW). ${ }^{36}$ During the preparatory works of the Commission of Jurists, the parameters of what aircraft would be classified as military

28. The custom in 'progress' or in statu nascendi was called by the Oppenheim as 'usages' (L Oppenheim, International Law: A Treatise: Vol II: War and Neutrality (Longmans Green and Co, London 1905) 24). The difference between customs and usages refers to the binding power. Usages are practices, which are not yet considered to be already crystallized ('hardened') norms, but have a capacity to become such through the recognition of their legal value.

29. In the past, there have been certain controversies regarding the status of balloonists as prisoners of war. During the Franco-Prussian War (1870-71), the Prussian government claimed that the crew members of the French balloons, captured behind the frontline, would be treated as spies. The Bismarck viewpoint protested both the states and international law experts, and the matter was ultimately settled in the 1874 Brussels Declaration (Art 22) and 1899/1907 Hague Peace Conferences (C Stockton, Outlines of International Law (Scribner's sons 1914) 355).

30. The first elements of the 'warship' definition were indicated in the 1856 Paris Declaration, which impose the prohibition of privateering.

31. F Dedele, 'Overflight by Military Aircraft in Time of Peace' (1967) 9(5) The United States Air Force JAG Law Review 14-15.

32. "The requirement of "bearing the external marks" is closely linked with the powers warships enjoy under international law. Since many of such powers are exclusively reserved to warships they are under an affirmative obligation to distinguish themselves from other state ships and to identify their nationality. Ships not bearing such external marks do not qualify as warships and are not allowed to perform any of the acts reserved for such ships'; W Heintschel von Heinegg, 'The Law of Military Operations At Sea' in T Gill and D Fleck (eds), The Handbook of the International Law of Military Operations (Oxford University Press, Oxford 2010) 338-39.

33. Interesting observation regarding the 'personification' of military aircraft in times of war have been conducted by Alex Meyer. See A Meyer, Volkerrechtlicher Schutz der friedlichen Personen und Sachen gegen Luftangriffe (Ost-Europa-Verlag 1935).

34. Although in 1971 Hamilton De Saussure seemed to question the character of the rule. See Hamilton DeSaussure, 'The Laws of Air Warfare: Are There Any?' (1971) 24(2) International Lawyer 527, 548.

35. Rolland (n 26) at 518.

36. Rules concerning the Control of Wireless Telegraphy in Time of War and Air Warfare. Drafted by the Commission of Jurists at The Hague, December 1922-February 1923. 
were considered uncontroversial and a reflection of the de lege lata. ${ }^{37}$ Article 3 of the HRAW underlined that the status of the air vessels should be evaluated by an 'external mark indicating its nation and military character'. ${ }^{38}$ The provision entails a novelty in the additional requirement for the marking, which should not only indicate its nationality but also 'military character'. However, this amendment should be considered only a technical addition: the practice of the belligerents during World War I clearly confirmed that military aircraft bear markings which are clearly attributable to the air forces, although they are not an exact presentation of the national flag or coat of arms. ${ }^{39}$ They are rather an exemplification of the national colours or very distinctive symbol of the state: for example White Star for the US or the Three-Crown insignia of the Swedish Royal House. This practice was widely observed during the time of drafting of the HRAW and was generally followed by the newly formed air forces after 1945, 1960 and $1991 .^{40}$

The penalty for not fulfilling the conditions listed in Article 3 of the HRAW is the loss of 'military aircraft' status. Thus, an aircraft which failed to meet the abovementioned requirements would not be entitled to act as a legitimate 'war engine' ${ }^{41}$ In case of capture, the status of the crew would be equal to a civilian taking a direct part in hostilities. The practice of World War I and World War II confirmed the prohibition of the use of false or neutral marks as a legitimate ruse of war (even if the aircraft is used in naval service) ${ }^{42}$ Both sides of the conflict captured several pieces of the enemy's equipment painted in national markings, which was later removed and repainted. ${ }^{43}$

37. 'Some of these rules were a statement of existing practice, e.g., a military aircraft shall bear an external mark indicating its nationality and military character, and such marks shall be so affixed that they cannot be altered in flight'; WG Downey, 'Revision of the Rules of Warfare' (1949) 43 Proceeding of The American Society of International Law Proceedings 107-08.

38. 'A clear distinction must be made between aircraft which form part of the combatant forces in time of war and those which do not. Each class must be easily recognisable; this is essential if the immunities to which non-combatant aircraft are entitled are to be respected'; Commission of Jurists to Consider and Report Upon the Revision of The Rules of Warfare - General Report (1924) ILS 109.

39. E Castren, Ilmasota - kansainvälisoikeudellinen tutkimus (Suomalaisen Lakimiesten Yhdisyksen Julkaisuja 1938) 130.

40. Slovak Air Force aircraft do not display the typical air force roundel, but the coat of arms of the Slovak Republic. On the other hand, the roundel had been used by the air force of the Slovakian State (Third Reich 'satellite' state) and by the air-independent squadron of the Slovakian insurgents in 1944. The national coat of arms is also used by the Ukrainian and Serbian Air Forces. One of the most often changing national air force insignia belongs to the Hungarian Air Forces, Bulgarian Air Forces and Afghanistan Air Forces, which were redesigned over 7 times between 1914-91. The new insignia reflected the political shifts in government structures.

41. 'The use of privateers in naval warfare was abolished by the Declaration of Paris, 1856 . Belligerent rights at sea can now only be exercised by units under the direct authority, immediate control and responsibility of the State. This same principle should apply to aerial warfare.' Commission of Jurists (n 38) at 234.

42. 'Although there are no conventional rules regulating the marking of aircraft in time of war, the practice of belligerents during World Wars I and II would appear to indicate acceptance of a prohibition against the false marking of aircraft in order to deceive an enemy.' RW Tucker, 'The Law of War and Neutrality at Sea' XIX [1955] ILS 142; 'Aircraft, including naval aviation, may not use false markings, however.' 'The Tanker War and The Law of Armed Conflict (LOAC)' (2000) 74 ILS 425.

43. German Luftwaffe established a special air detachment KG 200 (Kampfgeschwader 200), 
What is more ambiguous is the situation of the aircraft bearing no markings at all. In the case of the Israeli air force attack against the USS Liberty on 8 June 1967, Walter Jacobsen claimed that the use of unmarked aircraft was a violation of the customary rule "that military aircraft, when operational, must be distinctively marked with their nationality and military character' ${ }^{44}$ On the other hand, the 1976 Air Force Pamphlet 110-31 stipulated that in some circumstances such markings 'are not required', giving the example of closed airspace. ${ }^{45}$ The 2014 Air Force Operations and the Law highlighted that markings are not necessary 'where a particular kind of aircraft is only operated by the military of a particular state' ${ }^{46}$ In fact, there is a very limited range of circumstances where the lack of insignia would not undermine the duty to distinguish and is rather impossible in the context of international armed conflict. The remark of the Air Force Operations and the Law manual seems to be unacceptable simplification, as the overall design of military aircraft (unmanned and autonomous included) is rather universal. The UK's Joint Service Manual of the Law of Armed Conflict (JSP 383) highlighted that, regardless of the function of the military aircraft, the duty to display markings is not unburdened by the character of the plane. ${ }^{47}$ On the other hand, the failure to mark the aircraft would cause significant operational (inability to verify the nationality) and legal (definition of the military aircraft) consequences. ${ }^{48}$ Military markings on the aircraft assume the role of a protective 'umbrella' for the crew, even if the flying personnel are not in uniform, as the obligation to distinguish is already satisfied by the aircraft itself. ${ }^{49}$ On the other hand, it should be underlined that, due to the lack of 'combatant' concept in non-international armed conflict, there is no requirement for the parties of internal conflicts to mark their military aircraft. ${ }^{50}$

which was tasked to fly and evaluate the captured Allied aviation equipment. The existing documentation confirmed that previous national markings were removed and replaced with the Luftwaffe signs (including the famous B-17 Flying Fortress picture). Similar practice was observed in regard of captured German planes (Royal Air Force unit called Rafwaffe) and occurred in occupied Philippines (as the damaged USAAF B-17 were restored by the Japanese aviation. See RC Mikesh, 'Japan's Little Fleet of Big American Bombers' (1968) 52 Air Force and Space Digest: The Magazine of Aerospace Power 84-85).

44. WL Jacobsen, 'A Juridical Examination of the Israeli Attack on USS Liberty' (1986) 36 NLR 112.

45. Air Force Pamphlet 110-31 (AFP 110-31), at paras 7-4, 7-2.

46. Air Force Operations and the Law, Third Edition 2014 (Judge Advocate General's School 2014) 21 . The manual did not provide any further explanation in this regard, but it could be presumed that 'particular kind of aircraft' might be associated with surveillance and long range-reconnaissance $\mathrm{U} 2$ planes.

47. 'Military aircraft can include, for example, transport, reconnaissance, and meteorological aircraft of the armed forces of a particular state whether or not they are used in a direct combatant role. These aircraft must bear external markings indicating clearly their nationality and military character.' See Joint Service Manual of the Law of Armed Conflict JSP 383, at para 12.10.4, 311. 48. 'If the markings are erased altogether from military aircraft, they are no longer entitled to engage in attacks - or to exercise any other belligerent rights (...) in view of the fact the aircraft no longer meet the definitional requirements of military aircraft.' The Program on Humanitarian Policy and Conflict Research (HCPR) at Harvard University, see commentary in Manual of International Law Applicable to Air and Missile Warfare (Cambridge University Press, Cambridge 2013) 311.

49. WH Boothby and W Heintschel von Heinegg, The Law of War: A Detailed Assessment of the U.S. Department of Defence Law of War Manual (Cambridge University Press, Cambridge 2018) 117.

50. 'In a non-international armed conflict, there is no customary international law requiring the 
The abovementioned norms are examples of the 'third category rules', which are characteristic for air warfare. ${ }^{51}$ According to Yoram Dinstein's observations - some provisions of the law of air warfare are unique in terms of whole of international humanitarian law, and cannot be derived by the analogy. ${ }^{52}$ The speed and rapidity of the aircraft actions was a flywheel for the normative solutions regarding the markings of military aircraft. Such considerations are not present in the context of land warfare, where there is no duty to mark, for example, tanks or armoured vehicles. ${ }^{53}$

\section{LOCATION OF THE MARKINGS}

From the operational viewpoint, the location of the markings is vital for swift visual identification, both by ground forces and other aircraft. During World War I, all belligerents painted their national insignia on all surfaces of the machines - side, top and bottom. This practice was confirmed as legally binding by the HRAW (Article 7) and the provision was not contested. ${ }^{54}$ Most of the markings were painted symmetrically on the fuselage (sometimes the rudder) and lower and upper surface of the wings. However, there were minor exceptions. For instance, the US Army aircraft applied National Star Insignia to 'each side of the fuselage' and 'on the upper surface of the left wing and on the lower surface of the right wing', creating a nonsymmetrical but legally compatible scheme of painting. ${ }^{55}$ Nevertheless, during World War II, as photographs demonstrate, Soviet aviation did not paint the 'Red Star' insignia on the upper surface of the wing, instead using two marks on the fuselage and rudder. ${ }^{56}$ However, the continuation of this practice in time of the Cold War in this aspect was not always constant. The Soviet MiG-17 presented in Riverside March Air Force Base in California does not bear the Soviet insignia on the upper surface of the wings

marking of military aircraft. As long as the government forces operate within the other rules of international law applicable during a non-international armed conflict, the government forces may use any type of aircraft with or without markings.' I Henderson, 'International Law Concerning the Status and Marking of Remotely Piloted Aircraft' (2011) 39(4) Denver Journal of International Law and Policy 10.

51. 'The legal rules, if any, governing air warfare must belong to one of three categories. They may be rules which either are applicable to all forms of warfare, or they may have been extended by analogy from land or sea warfare to air warfare or they are germane to air warfare.' G Schwarzenberger, 'The Law of Air Warfare and the Trend Towards Total War' (1959) 1(1) University of Malaya Law Review 121.

52. Y Dinstein, 'Air and Missile Warfare Under International Humanitarian Law' (2013) 52(1) Military Law and the Law of War Review 84.

53. K Ipsen, 'Combatants and Non-Combatants' in D Fleck (ed), The Handbook of Humanitarian Law in Armed Conflicts (Oxford University Press, Oxford 1995) 325.

54. 'The external marks required by the above articles shall be so affixed that they cannot be altered in flight. They shall be as large as is practicable and shall be visible from above, from below and from each side.' Rules concerning the Control of Wireless Telegraphy in Time of War and Air Warfare. Drafted by the Commission of Jurists at The Hague, December 1922-February 1923.

55. Department of The Army, Technical Manual, Painting and Marking of Army Aircraft, Washington 1986 7-2; Technical Manual, Exterior Finishes, Insignia and Markings Applicable to USAF Aircraft, TO 1-1-4 3-1.

56. Available at <https://pl.wikipedia.org/wiki/Plik:Mig-3_(14443606821).jpg> (accessed 1 October 2020). 
(double symbol of the Red Star on the fuselage and rudder). ${ }^{57}$ On the other hand, the same aircraft displayed in the Moscow Technical Museum has only one 'Red Star' on the rudder and presents the national markings on the wings. ${ }^{58}$ Aircraft from the period of the Polish People's Republic, stored in the Polish Aviation Museum in Cracow (MiG-15,17,21) displaying the Polish 'checkboard' followed the Soviet-style type of painting, with no insignia on the upper surface of the wings. ${ }^{59}$ The Bulgarian Air Force MiG-21 did not bear national insignia on the upper surface of the wings until their retirement in 2015.60 Moreover, the still active fleet of the MiG-29s owned by Bulgaria displayed only one Bulgarian Air Force roundel on the rudder, with no markings on the fuselage or wings. ${ }^{61}$ The F-16s of the Belgium Air Forces are marked with national flag on the rudder, but the traditional roundel is only painted on the upper surface of the wings. ${ }^{62}$ Aircraft operated by the USAF Air Mobility Command (e.g. C-5 Galaxy) have the National Star Insignia on both sides of fuselage, without any markings on the upper and lower surface of the wings. ${ }^{63}$

The provided examples of the 'depleted markings practice' are prima facie inconsistent with The 1923 Hague Rules requirements, stipulating the necessity of visible markings presented on all surfaces of the military aircraft (with no specific duty related to the exact location of the insignia). The ratio behind the provisions stems from practical reasons, as aircraft nationality was determined by visual recognition. ${ }^{64}$ Nevertheless, no formal protest was lodged during the Cold War against the abovementioned practice, and it is very doubtful whether such a claim could strip the aircraft of exercising the rights of belligerents. It could be argued that Article 3 of the HRAW stipulates that the 'military aircraft shall bear an external mark', using the noun in single form ('external mark') not plural ('external marks'). Moreover, Article 6 of the HRAW provided that the aircraft 'not compromised in art. 3 and art. 4 should be deemed to be private', indicating the possibility that the single 'external mark'

57. Available at $<$ https://www.jetphotos.com/photo/8302552> (accessed 1 October 2020).

58. Available at <http://www.epktspotters.org/bigphoto/17/Mikoyan_Gurevich/MiG-17_Fresco _A/Soviet_Union_-_Air_Force/Other_location/Moscow_-_Muzey_tekhniki_Vadima_Zadorozh nogo/Russian_Federation///7899> (accessed 1 October 2020).

59. Polish military aviation insignia is unique in this regard, as the only world example of the square symbol divided into four smaller squares with a white and red colour scheme. Polish military aviation aircraft, between 1918 and 1939, under the second paragraph of the Presidential Decree of 1 March 1930, were ordered to paint the insignia both on the upper and lower surface of the wings as well on both sides of the rudder ( 2 of the Presidential Decree regarding flags and other military insignia, of 1 March 1930, Journal of Laws of the Republic of Poland, Dz. U. 17 z 1930 r., poz. 129). After 1945 the Polish aviation accepted the 'Soviet-style' placement of markings and by recent legislation (2009) returned to the pre-war practice.

60. Available at $<$ https://50skyshades.com/news/events-festivals/bulgaria-retires-last-mig-21fighters $>$ (accessed 1 October 2020).

61. Available at $<$ https://seenews.com/news/bulgaria-approves-28-mln-euro-spending-toensure-mig-29-jets-airworthiness-548046> (accessed 1 October 2020).

62. Available at <https://www.planespotters.net/photo/166922/fa-131-belgian-air-forcegeneral-dynamics-f-16-fighting-falcon> (accessed 1 October 2020).

63. Since World War II, the US military aircraft insignia are painted on both sides of fuselage and 'on the upper surface of the left wing and on the lower surface of the right wing'. ('Exterior Finishes, Insignia and Markings Applicable to Aircraft and Misses', Technical Manual, TO. 1-1-14 (1969) Secretary of the Air Force) 3-1, 3-2.

64. "All these divergences from maritime practice are inspired by the tremendously greater rapidity of approach of aircraft and the great damage which even a single shot may inflict.' HA Gosnell, 'The Hague Rules of Air Warfare' (1928) 62 American Law Review 41. 
would be sufficient to maintain the 'military status' of the aircraft. On the other hand, according to the San Remo Manual (Article 13(j)), the constitutive element of 'military aircraft' definition is 'having the military marks' (plural). ${ }^{65}$ This requirement is confirmed by the wording of rule 1(x) of the HPCR Air and Missile Warfare Manual ('bearing the military markings of that state'). As we observed, the practice of states varies. Also, the new aviation designs make it sometimes impossible to place the insignia on all surfaces (e.g. for aircraft based on the 'delta wings' concept, where the classical fuselage is not present). It seems that the irregular location of markings, or lack of insignia on some surfaces of the military aircraft, have become an acceptable variety of the rule, embodied within the customary law of air warfare.

\section{LOW-VISIBILITY MARKINGS}

At the beginning of air warfare, the requirement of visibility, which enabled rapid identification of 'friend or foe', was more important than 'stealth' capacity (see the example of the famous Foker Dr.I 'The Red Baron'). ${ }^{66}$ During the late stages of World War II, the German Luftwaffe introduced an advanced scheme for aircraft camouflage. The differences in operational geographic areas (e.g. African and European theatre) and weather conditions (summer and winter seasons) demanded a more detailed type of painting, which would be more difficult to distinguish from the above. ${ }^{67}$ In such circumstances, the Balkenkreuz sign was considered an element compromising the camouflage and endangering the aircraft's survivability. Another reason was the deficit of black paint. To eliminate the bright and illuminating drawings from the surface of the airframe, the German Luftwaffe simplified the insignia colour scheme by removing the black core painting. Before 1939, Polish military aviation, in order to blend the airframe in the sky, painted their PZL P-11 fighters underneath in characteristic 'Polish-blue' camouflage paint. It is worth mentioning that Polish military aviation 'checkerboard' insignia has an intense white-red colour scheme. To reduce its visibility, the insignia placed on the lower side of the wings were applied without the white colour. ${ }^{68}$

The experience gained from World War II confirmed that, in some circumstances, the bright and decorative colour scheme of the national air force insignia might be a detrimental element for the aircraft's and the crew's survivability. As time progressed, the development of the radar reduced the need for the visual requirements of the air vessel. ${ }^{69}$ Air combat evolved from frontline combat to long-range engagements,

65. L Doswald-Beck (ed), San Remo Manual on International Law Applicable to Armed Conflicts at Sea (Cambridge University Press, Cambridge 2005) 91.

66. DJ Zimmerman, Top Gun: 50 Years of Naval Air Superiority (Quarto Publishing Group 2019) 72.

67. Lepage (n 5) at 46-48.

68. Available at <https://pl.wikipedia.org/wiki/PZL_P.11\#/media/Plik:PZL_P.11c_'39_-_2'_ (14336386246).jpg > (accessed 1 October 2020).

69. Even during World War II, pilots and air-defence operators determined the nationality of the incoming aircraft based on the overall shape of the machine. Visual detection was already a great problem, and as a result, there was a rapid increase in 'friendly-fire' incidents, especially when a new type of aircraft was deployed or the situation in the airspace was dynamic. For instance, in September 1939, Polish aviation reported multiple casualties from friendly aircraft or air-defence (as due to Luftwaffe superiority almost all aircraft were immediate qualified as hostile). 
where the enemy cruises under the sub-sonic speeds and missile guidance systems are capable of destroying aircraft even hundreds of kilometers away. The latest Russian design anti-aircraft system, S-400, is able to attack and destroy flying objects within a range of $385 \mathrm{~km} .{ }^{70}$ An updated version of the AIM-120 Raytheon air-to-air missiles has an operational range of $160 \mathrm{~km}$. Nowadays, the determination of the character of the aircraft in contemporary air warfare conditions is solely based on the radar signature. In light of such circumstances, the practical role of the markings (as a method of long-range identification) is marginal. ${ }^{71}$ On the other hand, the state still observes the requirements arising from the HRAW of 1923. In order to reconcile the conflict between the practical realities of the battlefield and the legal requirements, many states decided to adopt a new type of insignia (generally referred to as "low visibility'). The markings are usually repainted in gray-scale (e.g. US) or faded shades of colours (e.g. UK). Prima facie this practice is a violation of Article 13 of HRAW, which demands that the aircraft markings be 'visible'. On the other hand, as observed by M Schmitt, no single state has protested against the employment of low-visibility markings. ${ }^{72}$ This harkens back to Wolf Heinstchell von Heineeg's statement that the 'absence of any objection to widespread practice evidences its lawfulness'. ${ }^{73}$ The same approach had been accepted by the experts during the drafting of the HPCR Air and Missile Manual, stipulating that '(...) States do not consider this practice to be unlawful' ${ }^{74}$ Indeed, the new type of insignia is already presented in multiple state air forces. It has been accepted practice by the major military powers - the US (1st place in Global Firepower 2019 ranking), China (3rd), South Korea (5th), the UK (16th), Saudi Arabia (12th), Australia (28th), Canada (31st) and other states (e.g. NATO members, including Hungary, Slovakia, Portugal, Netherlands, Czech Republic). A new type of RAF insignia is visible on the state-of-the art multirole 5th generation Lockheed Martin F-35 aircraft. ${ }^{75}$

\section{UNNAMED MILITARY AIRCRAFT}

Since the 1990s, the air forces of multiple states have gradually developed the new concept of pilotless air platforms. Interestingly, in his 1902 air warfare legal code draft, Paul Fauchille recognized, in Article 32, the category of 'unnamed free balloons' (les ballons libres). ${ }^{76} \mathrm{He}$ classified such objects similarly to 'civilian balloons' and stated that they should be bound by the same rules, highlighting the need to maintain the 'nationality indication' requirement (enveloppe un pavillon d'une forme particulière indiquant leur nationalité). ${ }^{77}$ The French jurist had already seen the

70. Center for Strategic \& International Studies, Recalibrating U.S Strategy Towards Russia: A New Time for Choosing (Rowman \& Littlefield, Lanham 2017) 79.

71. US Congress, Office of Technology Assessment, Who Goes There: Friend or Foe?, OTA-ISC-537 (US Government Printing Office, Washington 1993).

72. MN Schmitt, 'Air Law and Military Operations' in T Gill and D Fleck (eds), The Handbook of International Law of Military Operations (Oxford University Press, Oxford 2011) 311.

73. W Heinstchell von Heineeg, 'The Law of Military Operations at Sea' in T Gill and D Fleck (eds), The Handbook of International Law of Military Operations (2nd edn, Oxford University Press, Oxford 2015) 391.

74. HPCR Commentary 40.

75. Available at <https://www.bbc.com/news/uk-44392148> (accessed 1 October 2020).

76. Annuaire De L'Institut De Droit International, Vol. XIX (Session de Bruxelles 1902) 85.

77. Ibid at 84 . 
military potential of unnamed air systems. ${ }^{78}$ Nevertheless, it was beyond imagination that such pilotless aircraft would be capable of conduct combat operations, attributable to conventional military aircraft. ${ }^{79}$ This impacted the later legal developments relating to the law of air warfare, and, as a consequence, the status of unnamed military aircraft was out of scope of the HRAW drafters. Obviously, this did not mean that pilotless aircraft were developed by the constructors.

The analysis of photographs from the World War II period provides intriguing conclusions. In 1941, during Winston Churchill's visit to the Royal Navy station, the pilotless de Haviland 'Queen Bee' drone was marked accordingly based on the schemes which were binding at the time in the Royal Air Forces. ${ }^{80}$ In 1943, the USAAF adopted a programme called 'Aphrodite', whose core principle was to convert obsolete versions of the B-17 Flying Fortress into pilotless, radio-controlled drones with explosives. The bombers displayed the national insignia of the USAAF. ${ }^{81}$ A similar pattern was observed in the case of the German Luftwaffe unnamed programme called 'Mistel' ${ }^{82}$ In conclusion, it can be observed that, at least during World War II, the military aircraft operating without crew on board still complied with the requirements characteristic for conventional military aircraft, including visible markings.

During the era of the Cold War, the practice of the states seems much more ambiguous. USAF deploying the 'Firefly' and 'Lightning Bug' reconnaissance drones purposely stripped them of any signs that would indicate their nationality. The actions of those air systems were usually conducted in the grayscale situation of intelligence and covert mission. The Soviet Tu-141 drone's existing airframes showcase the national markings of the USSR. ${ }^{83}$ On the other hand, there are reports that during the international armed conflicts which occurred in the 1990s over Iraq, Bosnia and Serbia, USAF 'Predator' drones were deployed without the National Insignia markings. The 'Predator', an unnamed vehicle shot down by the Serbian air defence in 1999 over the Kosovo area and currently on display in Museum of Aviation in Belgrade, bear no signs of national identification. ${ }^{84}$

The lack of physical presences of the crew undermines the logic of military aircraft definition. As stated above, the markings served two functions: operational and legal. Operational reasons are contemporarily very limited due to radar technology. In the

78. Ibid at 85 .

79. However, the first plan to perform the act of bombardment through pilotless balloons were sketched by the Austrian Army in 1849 against the military installation in Venice. Years later, during World War II, the Japanese tried to use the east-bound winds over the Pacific Ocean in order to deploy explosive balloons against the west coast of the US.

80. Available at $<$ https://pl.m.wikipedia.org/wiki/Plik:Winston_Churchill_and_the_Secretary _of_State_for_War_waiting_to_see_the_launch_of_a_de_Havilland_Queen_Bee_radio-controlled_ target_drone,_6_June_1941._H10307.jpg > (accessed 1 October 2020).

81. Available at <https://en.wikipedia.org/wiki/Operation_Aphrodite\#/media/File:B-17.jpg> (accessed 1 October 2020).

82. Available at <https://en.wikipedia.org/wiki/Mistel\#/media/File:Mistel-4s.jpg > (accessed 1 October 2020).

83. Available at <https://www.google.com/url?sa=i\&url=https $\% 3 \mathrm{~A} \% 2 \mathrm{~F} \% 2 \mathrm{Fwww}$.airteam images.com\%2Ftupolev-tu-141_05_russia_russianairforce_264053.html\&psig=AOvVaw1zs HWSo7RJjFYGYHbgdpf5\&ust $=1592321106068000 \&$ source $=$ images $\& c d=v f e \& v e d=0 C A I Q j$ RxqFwoTCND7xsGQhOoCFQAAAAAdAAAAABAO> (accessed 1 October 2020).

84. Available at <https://www.alamy.com/stock-photo-mq-1-predator-at-museum-ofaviation-in-belgrade-serbia-104790103.html> (accessed 1 October 2020). 
legal context, the national insignia placed on the aircraft provides multiple rights for the platform itself and grants the combatant status for the operators - as they are parts of the military aircraft definition. Ian Henderson and Bryan Cavanagh suggested that, in that matter the law of air warfare, it is 'moving away from the law of naval warfare and towards the law of ground warfare', where there is no duty to mark military vehicles, considering that the 'customary international law applicable to military aircraft' started to lose 'its military significance'. ${ }^{85}$ Despite this remark, William Boothby underlined that if the unmanned aircraft are going to be allowed to perform the act of hostility, they need to fulfill the definition of military aircraft (markings included). 86

From the author's viewpoint, the latter opinion has more legal support behind it. In the existing framework, the definition of military aircraft is, leaving aside the definition of military objective, a rule of paramount importance in law of air warfare. Is it true that the international humanitarian law, especially in the customary law layer, is potent to what the International Military Tribunal described as 'continual adaptation', which 'follows the needs of a changing world' ? ${ }^{87}$ Nevertheless, the elements of military aircraft definition remain unchanged, despite the differences in technical realities. It might be argued whether the category of 'e-markings' would be a sufficient replacement to the traditional insignia. The authority controlling the airspace (civilian or air defence management) is determining the nationality of the aircraft (manned or unmanned) by their radar signature and identification signs - for example the specific number of flight or special transponder codes. While it seems to be a totally valid argument in the case of civilian traffic control, it is dangerous to believe that the 'e-recognition' of the military aircraft would respect the law of air warfare in the time of armed conflict - especially the principle of distinction and the definition of the military aircraft. For instance, Turkey's latest attempts to acquire Russian S-400 anti-aircraft missiles are meeting with strong opposition from the US. ${ }^{88}$ The S-400 platform is not designed to cooperate with the US-made IFF (Identification, Friend or Foe) system, which would pose a great threat to the NATO operations. Without the implementation of the aforementioned system, the anti-aircraft missiles are considering every aircraft and UAV (regardless of the character) as hostile. ${ }^{89}$ On the contrary, the negative verification done by the IFF system does not necessarily render the aircraft as a potential 'enemy', but classified it as an 'unknown' object, where additional verification is requested. In fact, this entails the 'old-fashioned' method of visual recognition. Any radio or radar-based identification is also vulnerable to countermeasures or other interference and eventual error might even result in loss of

85. I Henderson and B Cavanagh, 'Unmanned Aerial Vehicles: Do They Pose Legal Challenges?' in H Nasu and R McLaughlin (eds), New Technologies and the Law of Armed Conflict (Asser Press, The Hague 2014) 198.

86. WH Boothby, Weapons and the Law of Armed Conflict (2nd edn, Oxford University Press, Oxford 2009) 244. See also M Wagner, 'Unmanned Aerial Vehicles' in F Lauchemann and $\mathrm{R}$ Wolfrum (eds), The Law of Armed Conflict and The Use of Force: The Max Plank Encyclopaedia of Public International Law: Thematic Series Volume 2 (Oxford University Press, Oxford 2017) 1284 at para 22.

87. Trial of the Major War Criminals Before the International Military Tribunal 14 November 1945-1 October 1945 (Vol 1, Nuremberg 1947) 221.

88. Available at <https://www.reuters.com/article/us-turkey-security-usa/turkey-says-u-soffering-patriot-missiles-if-s-400-not-operated-idUSKBN20X1I8> (accessed 1 October 2020). 89. The IFF system is based on radio-encrypted connection between the transponder and so-called 'interrogator', operating on the restricted sets of frequencies. 
life and property - just like the tragic failure to distinguish the Iran Air Flight 655 from the Iranian Air Force F-14 or the 2003 shootdown of the Royal Air Force Tornado by the Patriot system. ${ }^{90}$ In consequence, the 'e-markings' or 'electronic identification' is not a sufficiently stable and reliable method of marking military aircrafts, when compared to the traditional requirement. Codes, call signs or radio signals, however useful and overwhelmingly dominant factors in air defence identification, cannot replace the 'ultimate role' of the physical insignia. Markings are constant and served as a source of the aircraft nationality and its status, even in cases of shootdown or destruction. ${ }^{91}$ Moreover, while the use of improper markings is prohibited and might in some circumstances be tantamount to perfidy, the use of the false IFF signature is a lawful ruse of war. 92

Despite the theoretical alternative means of distinction - as described in the paragraph above, the contemporary practice of states emphasize that unnamed aerial vehicles in military service have visible markings painted. This is confirmed by the photographic evidence of the UAVs operated by the US, ${ }^{93}$ Russia, ${ }^{94}$ the UK, ${ }^{95}$ Israel, France, ${ }^{96}$ Greece, ${ }^{97}$ Spain, ${ }^{98}$ Italy, ${ }^{99}$ Germany, ${ }^{100}$ Turkey, ${ }^{101}$ Argentina, ${ }^{102}$ Nigeria, ${ }^{103}$

90. The tragedy of the Iran Air 665 lies in the imposition of the IFF modes. While the Airbus A300 uses the IFF Mode 3 restricted for commercial traffic, the crew of the USS Vincennes classified the signal as a military Mode 2. See DK Linnan, 'Iran Air Flight 655 and Beyond: Free Passage, Mistaken Self-Defense, and State Responsibility' 1991 16(2) YJIL 253. In the case of the Patriot missile, it has been suggested that a serious malfunction of the Tornado's IFF onboard systems occurred and ignited the response from the anti-aircraft launchers.

91. Refer to the photograph relating of the destroyed MiG-21 of the Indian Air Force, downed in Pakistan 2019. Available at <https://fighterjetsworld.com/latest-news/pakistan-releasedetails-of-iaf-mig-21-fighter-jet-wreckage-shot-down-in-pakistan-territory/10948/> (accessed 1 October 2020).

92. 'IFF codes are not distress codes. The false use of the enemy's IFF Codes is not prohibited.' HPCR Commentary 312.

93. Available at $<$ https://en.wikipedia.org/wiki/File:MQ-9_Reaper_UAV_(cropped).jpg > (accessed 1 October 2020).

94. Available at <https://theaviationist.com/2019/08/07/video-russias-new-su-70-okhotnik-bor-hunter-b-drone-makes-first-flight/> (accessed 1 October 2020).

95. Available at <https://ukdefencejournal.org.uk/taranis-stealth-drone-test-flights-successful/> (accessed 1 October 2020).

96. Available at <https://www.ainonline.com/aviation-news/defense/2014-06-27/francekeeps-harfang-uas-despite-reaper-buy $>$ (accessed 1 October 2020).

97. Available at $<\mathrm{http}: / /$ greekmilitary.net/uav.htm $>$ (accessed 1 October 2020).

98. Available at <https://cdn.thediplomatinspain.com/wp-content/uploads/2014/07/dronesweb.jpg $>$ (accessed 1 October 2020).

99. Available at <https://www.africanmilitaryblog.com/wp-content/uploads/2019/11/2192 2702_2.jpg > (accessed 1 October 2020).

100. Available at <http://globalmilitaryreview.blogspot.com/2012/08/german-luftwaffesheron-2-high-altitude.html> (accessed 1 October 2020).

101. Available at <https://www.aljazeera.com/news/2020/03/battle-idlib-turkey-drones-war200303170724302.html> (accessed 17 June 2020).

102. Available at <https://www.uasvision.com/wp-content/uploads/2016/07/Vigia2A3.jpg> (accessed 1 October 2020).

103. Available at <https://www.airforce-technology.com/news/nigerian-air-force-inducts-firstindigenous-uav-support-isr/> (accessed 17 June 2020). 
South Korea, ${ }^{104}$ Australia ${ }^{105}$ and Ukraine. ${ }^{106}$ The 'especially affected' states are still following the old-fashioned requirement, forged on the battlefield of World War I and elaborated in a document almost 100 years old. ${ }^{107}$

Unlike the vehicles in land warfare, military aircraft have 'personification' in air and naval warfare by becoming a subject of legal provisions. ${ }^{108}$ From this 'personification' stems sets of concrete rights and immunities: for example the right to search and visit a vessel, ${ }^{109}$ the right of hot pursuit, ${ }^{110}$ the right of transporting wounded, sick or shipwrecked, ${ }^{111}$ immunity against seizure, ${ }^{112}$ and the fundamental right to perform acts of hostilities. ${ }^{113}$ Is it lawfully possible for military aircraft to perform those functions without being marked? In the author's opinion, the answer is no. Every dimension of warfare develops its own unique method for complying with the principle of distinction, using its dedicated system of identification, which is based on logical circumstances. In the case of land warfare, this means combatants display a 'fixed emblem'. In naval warfare, every warship presents its flag. The law of air warfare asserts that military markings are an essential element of the military aircraft definition. It has to be accepted that the reality of air combat has changed over the course of history, and visual recognition is no longer a primary source of identification. On the other hand, there are no clear reasons which support the idea of abandoning the obligation to mark military aircraft. Modern markings, by their decals, layouts, shapes or colours, do not compromise the camouflage of the aircraft and situations might still occur where the nationality of the aircraft is determined by sight

104. Available at <https://defence-blog.com/news/south-korean-medium-altitude-uav-conductednew-test-flights.html> (accessed 17 June 2020).

105. Available at <https://www.thedrive.com/the-war-zone/21779/australia-seals-deal-to-buymq-4c-drones-as-military-competition-in-the-pacific-heats-up> (accessed 17 June 2020).

106. Available at <https://www.unian.info/war/10460883-ukrainian-military-tests-modernizedspectator-m1-uav-video.html > (accessed 17 June 2020).

107. North Sea Continental Shelf, Judgement, I.C.J. Reports 1969 at para 73.

108. J Zhou, Fundamentals of Military Law: A Chinese Perspective (Springer, Beijing 2019) 511.

109. Rule 118, San Remo Manual on International Law Applicable to Armed Conflicts at Sea (12 June 1994) at Art 110(4) 1982 UNCLOS.

110. Art 111(5) 1982 UNCLOS under condition that they are 'clearly marked and identifiable'. 111. Art 15 IV GC o 1949.

112. M Bourbonniere et al, 'Military Aircraft and International Law: Chicago Opus 3' (2001) 66 Journal of Air Law and Commerce 891.

113. The wording of Art XVI of the HRAW at first glance contravenes the stipulations listed in the Air Missile Warfare Manual of 2009. According to the 1923 Regulations, the term hostilities 'include the transmission during flight of military intelligence for the immediate use of a belligerent'. On the other hand, the AMW does not provide a clear reference on what is considered as an act of hostility in air warfare. Rule 115(b) stipulates that, regardless of the perfidious character, it is unlawful to 'Use of any aircraft other than a military aircraft as a means of attack'. The AMW tends to narrow the scope of the 'hostilities' in air warfare only to active participation in combat operations, in comparison to Art XVI of the HRAW, which accept acts of intelligence and reconnaissance as a part of hostilities. In conclusion, the Air Missile Warfare Manual indicates that the 'hostilities' in air warfare are limited only to kinetic missions, leaving aside the question of transport, refuelling and intelligence operations. While rule 17(a) of the AMW stipulates that 'Only military aircraft, including UCAVs, are entitled to engage in attacks', Art XVI of the HRAW uses the word 'hostilities', which significantly extended the scope of the provisions. 
(e.g. the interception of the civilian airliner in the zone of an armed conflict). ${ }^{114}$ The concept of combatancy emanates from the overall duty of belligerents to distinguish. ${ }^{115}$ Even in the context of cyber warfare, a majority of scholars still accept the classic notions formulated in the 1899 and 1907 Hague Peace Conferences. ${ }^{116}$ If one combines the overall duty to present is combined - 'fixed emblem', 'flag' and 'military markings' - with the notion of combatant privilege, there are even more factors which appeal to continuation of the old-fashioned practice. ${ }^{117}$

The abovementioned conclusion is supported by the operations conducted by other entities existing in international law. The most relevant case is NATO's aviation, including both unnamed and manned platforms, having NATO markings painted on the fuselage. ${ }^{118}$ It has to be underlined that the international government organizations (IGO) are subjects of international law. Legal personality is well-established in the case of the United Nations and other IGOs, however their legal 'independence' is limited by the organization's 'purpose' and 'objectives'. ${ }^{119}$ In fact, the UN Charter in many provisions refers to the possibility to deploy armed force as an element necessary to conduct the primal objectives of the organization, for example the main responsibility to 'maintain international peace and security', while NATO is a military alliance. ${ }^{120}$ It has to be noted that there has been a discussion as to what extent the peace-keeping forces operating under the UN mandate shall be bound by the rules and customs of warfare, while the organization is not a party to international humanitarian law treaties. ${ }^{121}$ The starting point was establishing whether the IGO have the capacity to became a 'party to armed conflict' and be mutatis mutandis a subject of the law governing the conduct of armed conflict, including the legal regime concerning air warfare. Since the nineteenth century the institution called as a 'recognition of belligerency' opened a gateway to accept the legal personality within the law of armed

114. Even if taking into account the stealth aircrafts, it should be highlighted that their 'invisibility' is related to the negative radar signature, not the visual recognition. But see I Henderson and P Keane, 'Air and Missile Warfare' in R Liivoja and T McCormack (eds), Routledge Handbook of the Law of Armed Conflict (Routledge, Abingdon 2016) 285.

115. Convention (III) relative to the Treatment of Prisoners of War. Geneva, 12 August 1949, Commentary of 2020, Art 4: Prisoners of War at paras 983-87.

116. "Combatant status requires that the individual wear a "fixed distinctive sign". The requirement is generally through the wearing of uniforms. There is no basis for deviating from this general requirement for those engaged in cyber operations.' Tallinn Manual on The International Law Applicable to Cyber Warfare (Cambridge University Press, Cambridge 2013) at para 1096.

117. Y Dinstein, The Conduct of Hostilities under the Law of International Armed Conflict (3rd edn, Cambridge University Press, Cambridge 2016) 53.

118. In November 2019 the first NATO's RQ-4 Global Hawk's arrived to Sigonella, Italy as a part of the Alliance Ground Surveillance (AGS) programme. See more at <https://www.nato.int/ cps/en/natolive/topics_48892.htm> (accessed 1 October 2020).

119. Reparation for Injuries Suffered in the Service of the United Nations, Advisory Opinion, ICJ Reports 1949, 9.

120. 'In other words, the substantive capacity to use armed forces entails the subjective capacity to be bound by international humanitarian law norms.' G Porretto and S Vite, 'The Application of International Humanitarian Law and Human Rights Law to International Organisations' (2006) 1 University Center for International Humanitarian Law Research Paper Series 19.

121. Dame R Higgins, P Webb, D Akande, S Sivakumaran and J Solan, Oppenheim's International Law: United Nations, Volume I (Oxford University Press, Oxford 2017) 423; I Shearer, 'Rules of Conduct During Humanitarian Intervention' (2002) 78 ILS 77. 
conflict to other actors than states. ${ }^{122}$ The Additional Protocol to the Geneva Convention of 1977 accepts the subjectivity of the 'peoples' fighting with 'colonial domination' and 'alien occupation'. ${ }^{123}$ Given those circumstances, certain international organizations (e.g. NATO and UN) have the legal capacity to become the subject of IHL as a party of the armed conflict. ${ }^{124}$ The factual circumstances existing on the battlefield will provide more details in examining which actor of the multinational involvement under mandate or other authorization will be deemed as a party. ${ }^{125}$ This viewpoint seems to be widely accepted by the scholarship. ${ }^{126}$

As it was stated above, both UN and NATO established their own air detachments. In the case of the UN, under Article 3 of the Convention of the Safety of United Nations and Associated Personnel there exists a legal duty to 'bear distinctive identification'. ${ }^{127}$ On the other hand, Article 2(2) stipulates that the treaty is not applicable in case of 'enforcement action under Chapter VII' to which 'law of international armed conflict applies'. The Convention provides little guidance in the context of air warfare, but might serve as another argument (as per ad maius ad minori) supporting the necessity of marking potential combat aircrafts, serving the UN peacekeepers. ${ }^{128}$ More detailed sets of IHL obligations were formulated by the Secretary-General's Bulletin in 1999 and by analogy, by referring to 'fundamental

122. JW Garner, 'Recognition of Belligerency' (1938) AJIL 112.

123. Art 1(4) of Protocol Additional to the Geneva Conventions of 12 August 1949, and relating to the Protection of Victims of International Armed Conflicts (Protocol I), 8 June 1977.

124. 'An evolving interpretation of the law could be employed to contend that an international armed conflict exists whenever two or more entities possessing international legal personality resort to armed force in relations between them. Such an interpretation would make it possible to bring within the scope of IHL military action undertaken by international organisations, provided it reaches the threshold for the application of that body of law.' T Ferraro, 'The Applicability and Application of International Humanitarian Law to Multinational Forces' (2013) 95(891/892) IRRC 575; M Hirsch, The Responsibility of international Organizations Towards Third Parties: Some Basic Principles (Martinus Nijhoff, The Hague 1995) 36. On NATO see D Nauta, The International Responsibility of NATO and its Personnel During Military Operations (Brill, Nijhoff, The Hague 2018) 129.

125. Leuven Manual on the International Law Applicable to Peace Operations (Cambridge University Press, Cambridge 2017) at para 2-4 100.

126. K Macak, Internationalized Armed Conflicts in International Law ebook (Oxford University Press, Oxford 2018); S Wills, Protecting Civilians: The Obligations of Peacekeepers (Oxford University Press, Oxford 2009) 90; JK Keffner, 'Scope of Application of International Humanitarian Law' in D Fleck (ed), The Handbook of International Humanitarian Law (Oxford University Press, Oxford 2013) 53.

127. Convention on the Safety of United Nations and Associated Personnel New York, 9 December 1994.

128. The possibility of the misuse of UN markings was noted by the Report of the Panel of Experts concerning Darfur and classified as an 'obstruction of United Nations humanitarian operations'. 'NRF and SLA/MM have actively targeted personnel of the African Union Mission in the Sudan (AMIS) in Darfur, and the extensive use of white aircraft by the Government of the Sudan, including the use of white Antonov aircraft in some of the 66 aerial attacks catalogued by the Panel between September 2006 and July 2007, constitutes a serious obstruction to the work of AMIS and the United Nations. In one instance the Panel found that the Government of the Sudan had used a white Antonov aircraft with "UN" markings in offensive military overflights.' Report of the Panel of Experts established pursuant to resolution 1591 (2005) concerning the Sudan prepared in accordance with para 2 of resolution 1713 (2006) S.2007/584 5. 
principles and rules of the IHL' (section 1) and the principle of distinction (section 5), the overall reference to specific IHL norms might be decoded. ${ }^{129}$

On the other hand, the case of NATO is unique in this regard, as NATO is actively using own air platforms, for example the Global Hawk UAV and AWACS E-3 Sentry surveillance aircraft, as a part of alliance interventions since $1980 .{ }^{130}$ Existing photography confirms that NATO aircrafts are bearing characteristic NATO-OTAN descriptions on fuselage, as well the alliance symbol. ${ }^{131}$ The question remains whether such an act is effective under the law of air warfare. The HPCR Manual on Air and Missile Warfare underlines that the military aircraft could only belong to 'state' armed forces, leaving no further commentary regarding other entities of the international humanitarian law. ${ }^{132}$ Nevertheless, the manual in other places refers to the documents being applicable to 'armed conflicts involving any other international governmental organization, global or regional'. ${ }^{133}$ The legal aspects of NATO markings from the IHL perspective were reviewed by the Judge Advocate General (JAG) of the US Air Forces in 1980, during the process of delivery of the first E-3 Sentry to NATO. ${ }^{134}$ The opinion correctly stated that the binding power of duty to mark military aircraft, as well the definition of military aircraft, emerges from the customary international law. Under this condition it is not necessary to consider potential issues regarding the applicability of the international humanitarian law treaties and their relationship with legal entities other than states, which are also not formally a party to this treaty. ${ }^{135}$ By accepting the notion of subjectivity of the international organization as a legal person, NATO would be became an equal entity as a state under the law of air warfare. ${ }^{136}$ In consequence, in order to became a 'military aircraft', NATO air

129. Secretary-General's Bulletin Observance by United Nations forces of international humanitarian law (ST/SGB/1999/13).

130. NATO AWACs have been deployed in the Balkans and Libya, available at <https:// awacs.nato.int/operations/past-operations $>$ (accessed 1 October 2020).

131. Available at $<$ https://awacs.nato.int/media-center/photos\#pid=11> (accessed 1 October 2020).

132. HPCR Commentary 38; According to Yoram Dinstein military aircraft 'can only belong to the central government' (Y Dinstein, 'Air Warfare' in F Lauchemann and R Wolfrum (eds), The Law of Armed Conflict and The Use of Force: The Max Plank Encyclopaedia of Public International Law: Thematic Series Volume 2 (Oxford University Press, Oxford 2017) 24.

133. HPCR Commentary 57.

134. Civil Law Opinions of the Judge Advocate General United States Air Force 19781983325.

135. '(...) it is clear today that UN forces, and any other IO force for that matter, are bound by IHL when they are involved in armed conflicts as a matter of customary law'. N Zamir, Classification of Conflicts in International Humanitarian Law: The Legal Impact of Foreign Intervention in Civil Wars (Edgar Elgar, Cheltenham 2017) 175.

136. However, as observed by Christian Saja there is one important reservation regarding the treatment of an international organization as a 'party to the armed conflict' - the problem of territory, or more precisely the lack of it. It is not only a theoretical issue, but is creating friction with the limits of geographical scope of the permissible theatre of the air warfare. For instance, NATO AWACS E-3 Sentry aircrafts are stationed in Geilenkirchen, Germany. One would imagine an international armed conflict to which NATO is a party, and Germany is not (such a situation occurred during the Operation Unified Protector in 2011 when NATO E-3 aircrafts were redeployed to the Italian base in Trapani on Sicily and the German armed forces were not a part of the coalition). In these circumstances, Germany's permission to use its own airport and airspace in order to sustain NATO missions would be a flagrant violation of the laws of neutrality. The neutral state is requested to prevent entry of the belligerent aircraft into its own 
platforms need to fulfil all the requirements of the definition of military aircraft, including the duty to bear distinctive markings. As a result, NATO crews will benefit from the 'combatant privilege', rendering from prosecutions over espionage, as underlined by the JAG opinion of 1980. The case of NATO insignia in other evidence of international practice followed by other international law entities, validates the relevance of the markings as the constitutive element of the military aircraft definition, also in the context of unmanned platforms.

\section{CONCLUSION}

The law of air warfare is one of the most ambiguous parts of international humanitarian law. Its vagueness emanates from the fact that there is no dedicated treaty which comprehensively regulates all aspects of air warfare. This requires lawyers to extract and decode relevant norms from customary law. ${ }^{137}$ The obligation to mark military aircraft with the insignia indicating its military character was one of the legal provisions which emerged with the deployment of aircraft in a combat role. It has been universally accepted by the countries of the world, and during World War I, it achieved legal significance. Largely, the rule has been valid for over a century. From the state practice, it seems that there are two varieties of the norm, both of which seem to be permissible and uncontested. The first is the adoption of low-visibility markings as a compromise between the operational circumstance and legal restrictions. The second is the acceptance of the non-regular placement of the markings (in a nonsymmetrical way, which still fulfills the general obligation. Even breakthrough innovations in military aviation, such as unmanned and autonomous air platforms, have not challenged the validity of the provision embodied in Article 3 HRAW. Although there are those who question the duty to mark pilotless vehicles, the special status of military aircraft should be kept in mind, especially regarding the right to perform acts of hostility. As an integral part of the definition of military aircraft, there is no exception to the duty to properly mark aircraft.

airspace and in case of capture is responsible to intern both the crew and the aircraft. In fact, this would limit the geographical sphere of operations to the areas outside neutral jurisdiction (e.g. high seas) and the territory of belligerent states (if the counterpart to the armed conflict is a state). See C Saja, 'Multinational Peace Operations in Armed Conflicts - Identifying the Party' 2017(1) Institute for Human Rights Working Paper 19.

137. MN Schmitt, 'Air Warfare' in A Clapham and P Gaeta (eds), The Oxford Handbook of International Law in Armed Conflict (Oxford University Press, Oxford 2014) 119. 